Piotr Magier*

Lublin

\title{
Autorytety religijne w pedagogice. Uwagi metateoretyczne
}

Jednym z podstawowych warunków uprawiania nauki jest jej autonomia. W aspekcie instytucjonalnym realizacją postulatu autonomii nauki jest prawo do samostanowienia jednostek badawczych, jak na przykład posiadająca bogatą historię autonomia uniwersytetu. Problem wolności nauki nie dotyczy oczywiście wyłącznie aspektu instytucjonalnego. Jako przedsięwzięcie społeczne, nauka (naukowcy) podlega zależnościom ${ }^{1}$ środowiskowym, „ludzkim”2. Chodzi o sytuację, kiedy upowszechnienie określonych poglądów (tez, koncepcji, teorii) uzależnione jest od akceptacji różnych grup

* Dr Piotr Magier jest adiunktem w Instytucie Pedagogiki Katolickiego Uniwersytetu Lubelskiego Jana Pawła II, w Katedrze Pedagogiki Ogólnej. Adres: Instytut Pedagogiki KUL, ul. Droga Męczenników Majdanka 70, 20-325 Lublin; e-mail: piomae@kul.pl.

${ }^{1}$ Rozróżnienie autonomia - niezależność wprowadza Józef Maria Bocheński. Obie uznaje za istotny warunek rozwoju nauki: Józef Maria Bocheński, „Autonomia uniwersytetu”, w: Józef Maria Bocheński, Sens życia i inne eseje (Kraków: Wydawnictwo Philed, 1993), 61-66.

${ }^{2}$ Wypowiadanie pewnych poglądów jest niewątpliwie ryzykowne. J. M. Bocheński, krytykując humanizm, opisuje humorystycznie własną sytuację: ,jestem stary, nie mam już żadnej przyszłości i nic mi nie grozi od ludzi, zwłaszcza w kraju, gdzie uznaje się pewną wolność przekonań i gdzie w dodatku istnieje ubezpieczenie na starość. Staremu łatwiej pisać takie rzeczy niż młodemu, który musi się liczyć ze środowiskiem. Postanowiłem więc te rozważania ogłosić”: Józef Maria Bocheński, „Przeciw humanizmowi”, w: Józef Maria Bocheński, Sens życia i inne eseje (Kraków: Wydawnictwo Philed, 1993), 23. 
ludzi - najczęściej gremiów naukowców, lecz nierzadko również od uznania innych (tj. nie-naukowych) autorytetów.

Od wieków obserwować można próby podporządkowania nauki różnym ośrodkom władzy oraz próby wprowadzania ograniczeń w popularyzację określonych poglądów (koncepcji). Trudne dzieje związku nauki z polityką, ideologią czy religią sięgają starożytności (Sokrates, Hypatia). Specyficzna „równowaga” między nauką a systemem polityczno-religijnym ukształtowała się w średniowieczu, niemniej szczycąca się obiektywizmem i niezależnością nauka współczesna również obfituje w przykłady ograniczeń i nadużyć (np.: ideologiczne, antychrześcijańskie cele Wielkiej Encyklopedii Francuskiej, niechęć wobec osoby M. Curie-Skłodowskiej, profaszystowska postawa M. Heideggera, ideologiczne zaangażowanie R. Dawkinsa).

Problem wspomnianej zależności nie omija także pedagogiki. Najdobitniejszym tego przykładem są pedagogie: faszystowska, marksistowska oraz współczesne próby ideologizacji pedagogiki ${ }^{3}$. Historia zna zaangażowanie wybitnych pedagogów w projekty polityczne lub religijne budzące z perspektywy czasu wątpliwości lub dezaprobatę.

Przedmiotem niniejszego tekstu jest jeden z aspektów wspomnianej relacji, a mianowicie zależność między pedagogiką a poglądami osób uznawanych za autorytety religijne. W zasadzie formułowane uwagi interpolować można na relację między pedagogiką a autorytetami pozanaukowymi, niemniej literatura źródłowa dokumentuje zależność określoną w tytule tekstu. Dokładnie rzecz biorąc, chodzi o wykorzystanie w pedagogice koncepcji, twierdzeń i kategorii sformułowanych przez autorytety religijne. Zakres wypowiedzi ograniczam do dorobku pedagogiki (niekiedy szerzej - humanistyki) polskiej (tekstów polskojęzycznych). Opieram się w większości na tekstach autorów związanych z pedagogiką katolicką ${ }^{4}$, traktując je jako przykłady specyficznego, jednak wcale nie tak rzadkiego sposobu argumentowania.

3 Andrzej Bronk, „Czy pedagogika jest nauką autonomiczną?”, w: W trosce o integralne wychowanie, red. Marian Nowak, Tomasz Ożóg, Alina Rynio (Lublin: Wydawnictwo KUL, 2003), 65-67; zob. także: Roman Jusiak, „Refleksja o pedagogice i naukowych badaniach pedagogicznych", w: Szkice z pedagogiki, opieki międzyludzkiej, pracy resocjalizacyjnej i pedagogii chrześcijańskiej, red. Roman Jusiak, Andrzej Łuczyński, Lidia Pietruszka red., (Lublin: Wydawnictwo KUL, 2015), 15-17.

4 Świadomy jestem, że zasadność używania nazwy „pedagogika katolicka” podlega dyskusji w kontekście funkcjonowania innej nazwy, a mianowicie: „pedagogika chrześcijańska”. Sądzę jednak, że „bezpieczniej” jest użyć terminu „pedagogika katolicka” z uwagi na np. jej węższy zakres znaczeniowy, co wydaje się istotne w kontekście różnorodności poglądów (stanowisk) występujących w pedagogice chrześcijańskiej (chrześcijaństwie). Nie bez znaczenia 
Podjęcie niniejszego tematu uzasadnia znaczna liczba publikacji bądź bezpośrednio poświęconych pedagogicznym implikacjom dorobku określonych autorytetów religijnych - na przykład Jana Pawła II, Benedykta XVI, św. Jana Bosko czy Stefana Kardynała Wyszyńskiego, bądź aspektowo wykorzystujących określone kategorie, tezy, koncepcje autorytetów religijnych w badaniach wąskich zagadnień pedagogicznych ${ }^{5}$. Nie bez znaczenia dla wyboru tematu pozostaje również szerokie, społeczne zainteresowanie dorobkiem określonych osób, reprezentujących religię. Są to zjawiska, którymi - jak mniemam - pedagog ogólny, jako badacz pedagogiki, powinien być poznawczo zainteresowany.

Artykuł nie stawia sobie celów syntetycznych. Nie zamierzam postulować określonego modelu badanej relacji. W tekście chodzi raczej o sformułowanie elementarnych uwag dotyczących podjętego tematu. Wypowiedź ma zatem charakter analityczny i wprowadzający.

Jako autor niniejszej publikacji, z dwóch powodów znajduję się w dość niekomfortowej sytuacji. Po pierwsze, opis zjawiska może implikować także pewną ocenę. W tym kontekście środowiska naukowe, które wprost deklarują przywiązanie do autorytetów religijnych (lub szerzej religii - np. katolickie, z którym to środowiskiem sam jestem zresztą związany), mogą krytycznie bądź nieprzychylne odczytać niniejszy tekst. Chcąc uchronić się przed taką interpretacją mojej wypowiedzi, wyraźnie pragnę stwierdzić, że przedmiotem tekstu nie są poglądy, dorobek czy tym bardziej same osoby uznawane za autorytety religijne (bardzo często ja sam uznaję je za autorytety). Jest nim sposób wykorzystania dorobku, a niekiedy nawet samych osób (tj. ich imion i nazwisk) w pedagogice.

Po drugie, realizacja celu pracy wymaga odniesienia się do dorobku współczesnych pedagogów. Polemika z Koleżankami i Kolegami pedagogami jest sytuacją równie delikatną jak wskazana wyżej. Usprawiedliwia mnie, jak sądzę, jednak to, że zadaniem pedagoga ogólnego jest przede wszystkim prowadzenie badań metaprzedmiotowych, badań nad pedagogiką, jej dorob-

pozostaje także fakt istnienia tradycji użycia tej nazwy. Por. np.: Jacek Woroniecki, „Program pedagogiki katolickiej", w: Pedagogika katolicka. Zagadnienia wybrane, red. Alina Rynio (Stalowa Wola: Oficyna Wydawnicza Fundacji Uniwersyteckiej w Stalowej Woli, 1999), 18; Janina Kostkiewicz, „Status i tożsamość pedagogiki katolickiej 20-lecia międzywojennego w Polsce", Paedagogia Christiana 1 (2013): 45-69.

5 Przykładowo, o zakresie inspiracji myślą Jana Pawła II w pedagogice pisze Bogusław Śliwerski: http://sliwerski-pedagog.blogspot.com/2011/05/wkad-dzie-i-mysli-karola-wojtyy. html (21.08.2015). 
kiem treściowym oraz metodologicznym ${ }^{6}$. Nie można ich prowadzić inaczej jak tylko przez krytyczne odniesienie do tekstów pedagogicznych. Ponadto uznaję, że istotą nauki jest dyskusja. Bez niej nauka „umiera”. Poglądy, nawet opozycyjne, wyrażane w sposób rzeczowy i kulturalny, prowadzą do rozwoju nauki. Celem dyskusji nie jest pouczanie lub podważenie wartości osób wypowiadających określone tezy, ale dążenie do rozumienia. Jeśli argumenty oponenta są przekonujące, powinnością dyskutanta jest zmiana własnych poglądów, do czego jako autor niniejszego tekstu (osoba prowokująca dyskusję), jak sądzę, jestem zdolny?

\section{Historyczny kontekst problemu}

Problem zależności nauki od autorytetów pozanaukowych, w tym religijnych, nie jest zjawiskiem nowym i jednoznacznym (nieskomplikowanym) ${ }^{8}$. Jak wspomniałem we wstępie, sięga on początków procesu formowania się nauki (filozofii) w okresie starożytności greckiej. Można wręcz zaryzykować twierdzenie, że opisywana relacja w sensie genetycznym wchodzi w zakres definicyjnych problemów nauki. Wyodrębnienie nauki (filozofii ${ }^{9}$ ) spośród innych typów wiedzy (potocznej, religijnej, poetyckiej, technicznej) polegało bowiem na poszukiwaniu nieosobowych przyczyn zjawisk, odchodzeniu od religijnych uzasadnień przyjmowanych twierdzeń. Pewność wiedzy gwarantować miała racjonalna argumentacja, a nie osoba (jej cechy, pozycja społeczna) wypowiadająca określone poglądy ${ }^{10}$.

Istotnym dla ewolucji poglądów na temat zależności nauki od jej pozanaukowego kontekstu okresem historycznym było średniowiecze. Upo-

${ }^{6}$ Por. Piotr Magier, „Pedagogika ogólna w strukturze nauk pedagogicznych”, w: U podstaw tożsamości pedagogiki, red. Ryszard Skrzyniarz, Ewa Smołka, Stanisława Konefał (Lublin: Wydawnictwo KUL, 2012), 31-49.

7 Józef Maria Bocheński, „O dialogu filozoficznym”, w: Józef Maria Bocheński, Sens życia i inne eseje (Kraków: Wydawnictwo Philed 1993), 125-126.

${ }^{8}$ Por. Józef Maria Bocheński, Zarys historii filozofii (Kraków: Wydawnictwo Philed, 1993), 26.

9 Tezę o tożsamości nauki i filozofii w starożytności zawiera np. tekst Józefa M. Bocheńskiego: tamże, 15.

${ }^{10}$ Por. Władysław Tatarkiewicz, Historia filozofii. T. I. Filozofia starożytna i średniowieczna (Warszawa: Wydawnictwo Naukowe PWN, 1993), 19-21; Stanisław Kamiński, Nauka i metoda. Pojęcie nauki i klasyfikacja nauk (Lublin: Towarzystwo Naukowe Katolickiego Uniwersytetu Lubelskiego, 1992), 48; Bocheński, Zarys, 33. 
wszechnianie się i w konsekwencji dominacja chrześcijaństwa w krajach Europy oraz będące konsekwencją tego procesu ,zderzenie” chrześcijaństwa z kulturą antyczną doprowadziły do ponownego redefiniowania interesującej nas relacji. Problem funkcji autorytetu w nauce uznać można za osiowy dla ówczesnego modelu uprawiania nauki. Chrześcijaństwo jako religia opierało wiarę w prawdziwość własnej doktryny na autorytecie Boga, Objawieniu, świadectwie. Dorobek pogańskiej filozofii grecko-rzymskiej preferował natomiast rozum jako kryterium pewności tez. Interesującą konsekwencją fuzji chrześcijaństwa i filozofii antycznej okazała się scholastyka. Z jednej strony dopuszczała ona odwołania do autorytetów, z drugiej ograniczała prawomocność użycia tego typu argumentów (Piotr Abelard, Jan Szkot Eriugena, Berengariusz z Tours, Anzelm z Canterbury, Albert Wielki) ${ }^{11}$. Istotą scholastycznej metody naukowej stało się nie ślepe zaufanie autorytetom, lecz dyskusja twierdzeń. Odróżnienie obu typów uzasadnień uznać można za trwałe osiągniecie filozofii (nauki) średniowiecznej (św. Tomasz) ${ }^{12}$.

W aspekcie instytucjonalnym dialektyka niezależności i wpływu religii na naukę w wiekach średnich znalazła swe uszczegółowienie w funkcjonowaniu uniwersytetów. Prowadzenie badań naukowych pod mecenatem Kościoła nie pozostawało rzecz jasna bez konsekwencji dla samej nauki. Wydaje się, że przykładowo polegały one na konieczności zachowania zgodności treści określonych rezultatów badawczych (np. poglądów filozoficznych) z nauczaniem Kościoła (cenzura ${ }^{13}$ ) czy preferowaniu w nauce problematyki teologicznej i filozoficznej, przekładając się na dynamiczny rozwój tych dwóch dyscyplin oraz hierarchiczny model struktury uniwersytetu $^{14}$. Dążenie do niezależności nauki średniowiecznej w relacji do władzy Kościoła znalazło swe rozwinięcie w tworzeniu „nie-kościelnych” uczelni wyższych. Przykładami tego były uniwersytety włoskie, fundowane przez arystokratów (niekiedy przez władze miast). Charakteryzowały się one wła-

${ }^{11}$ Por. Bocheński, Zarys, 111; Gillian Rosemary Evans, Filozofia i teologia w Średniowieczu (Kraków: Wydawnictwo Znak, 1996), 77-80; Zdzisław Chlewiński, Stanisław Majdański, „Autorytet”, w: Encyklopedia Katolicka, T. I, red. Feliks Gryglewicz, Romuald Łukaszyk, Zygmunt Sułowski (Lublin: Towarzystwo Naukowe Katolickiego Uniwersytetu Lubelskiego, 1985), 1161-1162.

12 „W średniowieczu nastapiło jasne rozgraniczenie teologii od filozofii, tj. wiary od rozumu. Św. Tomasz definiuje filozofię słowami «wiedza rozumem nabyta» [...]”: Bocheński, Zarys, 22.

${ }^{13}$ Chlewiński, Majdański, „Autorytet”, 1163.

14 Por. Bocheński, Zarys, 94; Stanisław Kot, Historia wychowania. T. I (Warszawa: Wydawnictwo "Żak", 1996), 162. 
sną strukturą organizacyjną oraz specyficznym zakresem prowadzonych badań i dydaktyki (preferowaniem dyscyplin humanistycznych i przyrodniczych $)^{15}$.

Wydaje się, że próba zerwania związku nauki z religią, wyraźnie ewokowana od okresu renesansu (M. Montaigne, F. Bacon) ${ }^{16}$, nie doprowadziła do zadowalających rezultatów. Postulat neutralności (obiektywności) nie gwarantował niezależności i autonomii nauki, prowadząc niekiedy do ukrytych form jej podporządkowania ideologii lub polityce. Mimo zdecydowanych żądań uwolnienia nauki spod zależności religijnej, światopoglądowej, politycznej, czy nawet od założeń filozofii, nauce nie udało się pozostać neutralną. Zarówno sami naukowcy, jak i odkrycia naukowe pozostawały (i zapewne pozostaja) w związku $\mathrm{z}$ dominującym w danym okresie typem kultury, ideologia, światopoglądem czy modelem władzy ${ }^{17}$.

Co więcej, uformowane historycznie modele naukowości implicite wydają się bądź narzucać nieprzychylną ,atmosferę” dla wprowadzania autorytetów w strukturę procesu argumentowania, bądź przeciwnie - umożliwiać taki sposób argumentacji. Jak sądzę, nieprzychylny teoretycznie kontekst dla wprowadzania argumentów z autorytetu tworzą: pozytywizm oraz koncepcje relatywizujące istotę i wartość nauki - na przykład postmodernizm. Oprócz wspomnianej wcześniej scholastyki przyjazny „klimat” dla aspektowego wykorzystywania autorytetów pozanaukowych w nauce wydaje się generować nieklasyczna koncepcja racjonalności nauki oraz (w tym) filozofia nauk humanistycznych.

Teoretyczna opozycja wobec argumentowania tez przez odwołanie do wypowiedzi określonych autorytetów osadzona jest bądź na przekonaniu o konieczności zachowania w nauce ścisłości, zwłaszcza w aspekcie metod badań oraz języka (jak ma to miejsce w pozytywizmie i neopozytywizmie), bądź na przekonaniu o względności odkryć naukowych, ich czasowej i kulturowej ograniczoności. W ujęciach odwołujących się do koncepcji racjonalizmu oświeceniowego oraz pozytywistycznej koncepcji nauki wartość twierdzeń uzasadnia określona rygorystycznymi kryteriami metodologia badań. Nie ma w niej miejsca na przyjmowanie twierdzeń z uwagi na osoby

15 Kot, Historia, 154-156.

16 Chlewiński, Majdański, „Autorytet”, 1162.

17 Tradycja odmawiająca uniwersytetom autonomii sięga czasów reformacji i kontrreformacji: Bocheński, „Autonomia”, 61; por. także: Balázs M. Mezei, „Kryzys uniwersytetu”, Ethos 1-2 (2009): 40. 
wypowiadające tezy, zwłaszcza osoby niebędące naukowcami ${ }^{18}$. Natomiast koncepcje relatywizujące naukę o tyle wydają się nieprzychylne dla użycia argumentu z autorytetu, że uznanie wiedzy naukowej za względną podważa równocześnie ,prawdziwość” wykreowanych w jej ramach autorytetów. W skrajnych przypadkach twierdzenia traktuje się wręcz jako subiektywne poglądy pewnych osób, warunkowane kontekstem kulturowo-społecznym lub indywidualnymi przeżyciami. Nie bez znaczenia dla analizowanego problemu pozostaje także niechęć wobec autorytetów w ogóle oraz niechęć wobec religii, typowa dla stanowisk postmodernistycznych ${ }^{19}$.

Metodologiczny model nauk humanistycznych oraz nieklasyczne koncepcje racjonalności nauki ukształtowane w XIX i XX wieku wydają się natomiast (aspektowo) tworzyć przychylny „klimat” dla wprowadzenia argumentacji z autorytetu (a przynajmniej dla analiz dotyczących znaczenia podmiotu w procesie badań naukowych). Chodzi przede wszystkim o problem interpretacji (rozumienia) ${ }^{20}$ oraz problem osobowej gwarancji racjonalności twierdzeń naukowych ${ }^{21}$. Ponadto, bliskość metodologiczna dyscyplin humanistycznych oraz dorobku kultury powoduje zatarcie granic przedmiotowych i kompetencyjnych tak w ramach samej humanistyki, jak i w relacji nauk humanistycznych do kultury oraz religii. Niewatpliwie ich dorobek zachodzi na siebie i warunkuje się wzajemnie. Osiagnnięcia jednej dziedziny wiedzy/ kultury uznawane są za istotne dla innych, stanowiąc znaczący wkład i bazę dla wzajemnego rozwoju ${ }^{22}$.

Zależność tę dobitnie potwierdza historia pedagogiki. Zarówno rozwój praktyki edukacyjnej, jak i teorii pedagogicznej potwierdzają szeroki zakres wykorzystania dorobku różnych podmiotów. Formułowane w dziejach modele wychowania (pedagogie) niejednokrotnie tworzone były przez

18 Por. Monika Walczak, Racjonalność nauki. Problemy, koncepcje, argumenty (Lublin: Towarzystwo Naukowe Katolickiego Uniwersytetu Lubelskiego, 2006), 61-62, 64-67; Piotr Magier, „Aksjologiczno-normatywne i argumentatywne aspekty pedagogiki chrześcijańskiej”, w: Edukacyjny potencjat religii, red. Jerzy Bagrowicz, Jarosław Horowski (Toruń: Wydawnictwo Naukowe Uniwersytetu Mikołaja Kopernika, 2012), 178.

${ }^{19}$ Andrzej Bronk. Zrozumieć świat wspótczesny (Lublin: Towarzystwo Naukowe Katolickiego Uniwersytetu Lubelskiego, 1998), 41-42, 44-45.

${ }^{20}$ Por. Kamiński, Nauka i metoda, 148-150.

${ }^{21}$ Por. Walczak, Racjonalność, 135-136.

22 Por. Marian Nowak, „Edukacyjny potencjał pedagogiki religii - bogactwo doświadczenia ludzkiego do przekazania", w: Edukacyjny potencjat religii, red. Jerzy Bagrowicz, Jarosław Horowski (Torun: Wydawnictwo Naukowe Uniwersytetu Mikołaja Kopernika, 2012), $54-58$. 
osoby niezwiązane bezpośrednio $\mathrm{z}$ teorią pedagogiczną - $\mathrm{w}$ tym często przez przedstawicieli religii. Współczesny dorobek pedagogiki pozostawałby istotnie uboższy wyjąwszy działalność wychowawczą i towarzyszące jej poglądy formułowane w ramach religii, w naszym kontekście głównie w ramach chrześcijaństwa ${ }^{23}$.

\section{Pojęcia autorytetu religijnego i pedagogiki}

Mówiąc o funkcjach (wykorzystaniu) twierdzeń autorytetów religijnych w pedagogice, konieczne jest wyjaśnienie podstawowych dla opisywanej zależności kategorii: „,autorytet religijny” oraz „pedagogika”. Nie zamierzam przeprowadzać $\mathrm{w}$ tym aspekcie poszerzonej analizy ${ }^{24}$, niemniej dla klarowności wypowiedzi konieczne jest sformułowanie kilku pryncypialnych uwag.

Przez określenie ,autorytet religijny” rozumiem specyficzny typ autorytetu, czyli typ asymetrycznej relacji, polegającej na uznaniu „wyższości” pewnej osoby (grupy osób bądź instytucji) z uwagi na określone jej cechy ${ }^{25}$. W przypadku autorytetu religijnego relacja ta powstaje z uwagi na wyjątkowy status „religijny” jednego z podmiotów wchodzących w przedmiotową relację ${ }^{26}$. Może on dotyczyć również Objawienia jako takiego ${ }^{27}$.

Istotne wydaje się dalej klasyczne rozróżnienie między autorytetem epistemicznym a deontycznym ${ }^{28}$. Przyjmuję, że przez ,autorytet epistemiczny”

${ }^{23}$ Por. Jusiak, „Refleksja o pedagogice”, 14.

${ }^{24}$ Szerzej problem ten poruszam w takich tekstach jak: Piotr Magier, „Autorytet wychowawcy według koncepcji pedagogiki personalistycznej”, w: Personalizmus $v$ procese humanizácje l'udskej spoločnosti, red. Pavol Dancák (Prešov: Prešovská univerzita v Prešove, 2014), 283-289; Magier, „Aksjologiczno-normatywne”, 167-171, 177-182.

25 Por. Lidia Drabik i in. (oprac.), Stownik Języka Polskiego (Warszawa: Wydawnictwo Naukowe PWN, 2007), 31; Józef Maria Bocheński, Sto zabobonów. Krótki filozoficzny słownik zabobonów (Kraków: Wydawnictwo Philed, 1994), 24; Chlewiński, Majdański, „Autorytet”, 1161; Jarosław Horowski, „Wolność od autorytetu jako zabobon. Teleologia wychowania w zakresie autorytetu w świetle analiz Józefa Marii Bocheńskiego", Acta Universitatis Nicolai Copernici-Pedagogika XXV (2009): 32-33.

${ }^{26}$ W szczególności chodzić może o założycieli określonych religii, czyli o sytuację, z którą mamy do czynienia w przypadku Chrystusa oraz o pedagogikę chrześcijańską. Por. Marian Nowak, „Tożsamość pedagogiki chrześcijańskiej”, Paedagogia Christiana 1 (2013): 30-31.

27 Odwołania do Objawienia judeochrześcijańskiego wydają się stanowić istotny aspekt współczesnej pedagogiki w Polsce: jej bazę teoretyczną oraz płaszczyznę argumentacji: Magier, „Aksjologiczno-normatywne”, 177.

${ }^{28}$ Bocheński, Sto zabobonów, 24. 
określa się taki typ autorytetu, który odwołuje się do specyficznych cech, własności (np. wiedzy, kompetencji, umiejętności) jednostki. „Autorytet deontyczny" oznacza autorytet tworzony w oparciu o pozycję, jaką zajmuje jednostka w strukturze określonej społeczności lub instytucji. To zatem instytucja (system społeczny) uzasadnia ten typ autorytetu. Rzecz jasna zaproponowany podział nie jest rozłączny. Istnieje możliwość, że określone osoby są autorytetami zarówno ze względu na cechy osobiste, jak i pozycję/funkcję społeczną. Niemniej istotną możliwością jest ta, iż za autorytety uznajemy osobę wyłącznie ze względu na cechy osobowościowe bądź ze względu na jej pozycję instytucjonalną.

Autorytet religijny - podobnie - może mieć charakter epistemiczny lub/i deontyczny. Osoba uznawana za autorytet religijny może pełnić tę funkcję bądź z powodu specyficznych cech osobistych wchodzących w zakres jej religijności (np. doświadczenia mistyczne, własności moralne, wiedza religijna), bądź z powodu pozycji, jaką zajmuje w instytucjach/wspólnocie religijnej, bądź też z obu względów jednocześnie.

Jeśli chodzi o drugą kategorię - „pedagogika” - niezbędne wydaje się dookreślenie, że termin ten odnoszę do specyficznej nauki, nie zaś praktyki (określanej jako „edukacja” bądź ,wychowanie”). Doprecyzowanie to nie ma znaczenia wyłącznie metodologicznego. Chodzi mianowicie o to, że inne funkcje pełnią autorytety w edukacji, inne w pedagogice (tj. nauce). Ponieważ podstawowym zadaniem każdej nauki jest poznanie, formułowane uwagi w znacznej mierze dotyczą tej funkcji - zarówno w aspekcie heurystycznym, jak i w funkcji argumentowania. Niemniej wiadomo, że nauki humanistyczne, w tym pedagogika, pełnią także funkcje praktyczne - ocenne i postulatywne ${ }^{29}$. Zatem analizy funkcji autorytetu religijnego $\mathrm{w}$ pedagogice muszą dotyczyć także praktycznego celu tej nauki.

Analiza pedagogiki jako nauki wprowadza jeszcze jeden zbiór uwag dotyczących interesującej nas relacji. Chodzi o strukturę pedagogiki jako nauki. Przyjmuję, że w zakres struktury pedagogiki jako nauki wchodzą zarówno treści o charakterze opisowym (pochodzące najczęściej z nauk szczegółowych), jak i treści o charakterze normatywnym (te najczęściej określane są na podstawie dorobku nauk filozoficznych) ${ }^{30}$. Pytanie o funkcje autorytetów religijnych $\mathrm{w}$ pedagogice $\mathrm{z}$ konieczności zatem musi zawierać szczegółowe uwagi dotyczące wymienionych wyżej poziomów wiedzy pedagogicznej.

${ }^{29}$ Bronk, „Czy pedagogika”, 60-61.

${ }^{30}$ Por. Stefan Kunowski, Podstawy współczesnej pedagogiki (Warszawa: Wydawnictwo Salezjańskie, 2001), 49-62. 


\section{Funkcje autorytetów religijnych w pedagogice}

Zacznę od uwag stanowiących kontekst (background) analizowanych w niniejszym punkcie treści. Po pierwsze, istotna wydaje się odpowiedź na pytanie, czy „w ogóle” mamy prawo wykorzystywać autorytety w badaniach naukowych (w nauce). Historia nauki podsuwa przypuszczenie, że zależy to od modelu (paradygmatu) nauki, w ramach którego się poruszamy. Jak wspomniałem wyżej, jedne modele metateoretyczne uzasadniają taki zabieg, inne są względem niego sceptyczne lub wrogie. Niezależnie jednak od przyjętego paradygmatu nauki sądzić można, że argumenty z autorytetu nie są ostatecznymi sposobami uzasadniania twierdzeń w nauce. Racjonalne (zdroworozsądkowe) wydaje się przekonanie mówiące, że nie można przyjmować za pewnik twierdzenia o rzeczywistości wyłącznie(!) dlatego, że określona osoba tak twierdzi.

Warto - jak sądzę - w kontekście pytania o możliwość i potrzebę stosowania argumentów $\mathrm{z}$ autorytetu w nauce zwrócić uwage na wypowiedź J.M. Bocheńskiego, według którego rozwój nauki byłby niemożliwy bez odwołań do przyjmowanego na mocy autorytetu dorobku innych naukowców $^{31}$. Naturalną w nauce sytuacją jest, że dorobek ten stanowi punkt wyjścia dla dalszych badań i tym samym dla postępu nauki. Ciągła weryfikacja dotychczasowego dorobku powodowałaby sytuację, w której energię i czas poświęcano by na ocenę znanych już treści.

Uwaga ojca Bocheńskiego interpretowana może być ponadto w aspekcie dydaktycznym. Dorobek innych naukowców (np. klasyków określonej dyscypliny) przyjmowany bez konieczności dowodzenia wydaje się o tyle ważny dla rozwoju nauki, że stanowi treść edukacji przyszłych naukowców. Nawet jeśli przyjmiemy, że nauka realizowana jest głównie z powodów „egoistycznych” (poszerzania własnej wiedzy), jej trwanie wymaga wychowania nowych, młodych naukowców, będących w stanie sprawnie posługiwać się metodą naukową ${ }^{32}$. Właśnie tę potrzebę nauki wydaje się zaspokajać odwołanie do autorytetów, a właściwie ich poglądów, tez, koncepcji.

Innym problemem jest, czy autorytety pozanaukowe(!), na przykład religijne, mogą być wykorzystywane w nauce? Jeśli tak, to na mocy czego i w jakim zakresie? Problem zasadności wykorzystania autorytetów pozanaukowych w nauce wydaje się kwestią wchodzącą zakres dyskusji, dotyczą-

${ }^{31}$ Bocheński, Sto zabobonów, 25.

${ }^{32}$ Bocheński, „O dialogu filozoficznym”, 127-128. 
cych zależności między wiedzą naukową i nienaukową. Uznanie odrębności obu typów wiedzy (demarkacjonizm) utrudnia niewątpliwie wykorzystanie autorytetów religijnych w nauce. Co więcej, nakładanie się obu typów wiedzy traktowane jest jako sytuacja niepożądana czy wręcz niedopuszczalna ${ }^{33}$.

Odmienny sposób rozstrzygnięcia problemu zastosowania autorytetów religijnych w nauce generują koncepcje uznające zasadność współzależności wiedzy naukowej z innymi typami wiedzy, na przykład potoczną czy religijną, uznając „pluralizm nośników racjonalności nauki” (antydemarkacjoni$\mathrm{zm})^{34}$. Przyjmuje się w ich ramach współzależność różnych typów wiedzy, na przykład zależność genetyczną. W modelu antydemarkacjonistycznym stosowanie argumentów odwołujących się do autorytetów religijnych wydaje się zatem nie tylko możliwe, lecz naturalne ${ }^{35}$. Treści odpoznane w taki sposób „wzbogacają kapitał” wiedzy naukowej. Nadają jej charakter wieloaspektowy, inter- lub multidyscyplinarny ${ }^{36}$.

Podejście antydemarkacjonistyczne nie usuwa jednak konieczności rozstrzygnięcia uzasadnienia (na mocy czego) uznania danej osoby za autorytet religijny. Istotna jest odpowiedź na pytanie: czy pozycję autorytetu uzasadnia zespół cech przynależnych osobie czy pozycja, jaką zajmuje w strukturze grupy (instytucji) religijnej? Wydaje się, że najsłabszą formą uzasadnienia autorytetu jest jego instytucjonalna geneza (autorytet deontyczny). Pełnienie określonej funkcji w strukturze instytucji religijnych niekoniecznie musi wiązać się z przedmiotowymi kompetencjami, cechami osobowościowymi czy doświadczeniem, pozwalającymi osobie kompetentnie wypowiadać się $\mathrm{w}$ pewnej dziedzinie ${ }^{37}$. Co prawda, niektóre instytucje religijne aspektowo łączą funkcje instytucjonalne z kompetencjami merytorycznymi (nieomylność nauczania moralnego i dogmatycznego papieża), jednak w nauce zasada taka wydaje się nie obowiązywać.

Epistemiczny typ uzasadnienia autorytetu jest niewątpliwie „mocniejszy", pewniejszy. Szlachetność moralna, cechy osobowościowe, doświadczenie osobiste, a zwłaszcza posiadana wiedza i kompetencje stanowią istot-

33 Walczak, Racjonalność, 87-90.

34 Tamże, 125-137.

${ }^{35}$ Wydaje się, że właśnie taki model zależności między wiedzą potoczną i naukową w pedagogice przyjmuje Stefan Kunowski: por. Kunowski, Podstawy, 60-62.

${ }^{36}$ Marian Nowak, Podstawy pedagogiki otwartej (Lublin: Redakcja Wydawnictw KUL, 1999), 172-174.

${ }^{37}$ Bocheński, Sto zabobonów, 25-26. 
ny argument za uznaniem tego typu autorytetu ${ }^{38}$. Jak wspomniałem wyżej, pedagogika jako nauka „chętnie” odwołuje się do wiedzy uzyskanej poza nią samą. Dla określenia pewnych zakresów treści w pedagogice wydaje się ona wręcz niezbędna. Problem jedynie w tym, w zakresie jakich typów wiedzy pedagogicznej interpolacja tego typu jest zasadna i potrzebna.

Jeśli przyjmiemy zasadność wykorzystania autorytetów religijnych w pedagogice, jak wspomniałem wyżej, mogą one służyć bądź realizacji celów poznawczych, bądź praktycznych. W aspekcie poznawczym chodzi o sytuację, w której wypowiedzi (tezy) osób uznawanych za autorytety religijne uznaje się za tezy trafnie (prawdziwie) opisujące rzeczywistość, będącą przedmiotem badań pedagogiki. W aspekcie praktycznym chodzi o sytuację, w której wypowiedzi autorytetów religijnych stanowią podstawę do formułowania bądź uzasadniania ocen i postulatów.

Problem wykorzystania autorytetów religijnych w funkcji poznawczej (heurystycznej i argumentatywnej) niewątpliwie jest złożony. Badania prowadzone na terenie pedagogiki dotyczą różnych poziomów czy aspektów rzeczywistości. W zakres zainteresowań badawczych pedagogiki wchodzą zarówno zjawiska fizyczne, przyrodnicze, społeczne, humanistyczne, jak i zjawiska stanowiące przedmiot badań filozofii ${ }^{39}$. Jeśli więc uznajemy zasadność odwołań do autorytetów religijnych, istotne wydaje się dookreślenie zakresu kompetencji autorytetu oraz zakresu wiedzy pedagogicznej, do której ów autorytet możemy stosować. Uznawanie określonego autorytetu za kompetentny „we wszystkim” wydaje się postawą nieuzasadnioną, naiwną ${ }^{40}$, choć - jak myślę - nie tak rzadką.

Niewątpliwie typowy zakres wiedzy pedagogicznej, odpowiadającej kompetencjom autorytetów religijnych, stanowi wiedza o charakterze teologicznym i (przynajmniej zazwyczaj) filozoficznym - w tym etycznym ${ }^{41}$.

38 Tamże, 24-25.

${ }^{39}$ Nowak, „Tożsamość”, 26-28.

40 Por. Bocheński, Sto zabobonów, 25.

${ }^{41}$ Przykładowe prace pedagogiczne eksploatujące dorobek autorytetów religijnych w aspekcie teologicznym i filozoficznym to chociażby: Alina Rynio, Integralne wychowanie w myśli Jana Pawła II (Lublin: Wydawnictwo KUL, 2004); Marek Jeziorański, Bt. Jana Pawła II koncepcja wychowania malżonków (Lublin: Wydawnictwo KUL, 2013); Mariusz Sztaba (oprac.), Benedykt XVI. „Aby na nowo odkryć radość w wierze...”. Antologia papieskich wypowiedzi na temat wiary, watpienia $i$ ateizmu (Warszawa: Oficyna Wydawniczo-Poligraficzna ADAM, 2014); Zbigniew St. Iwański, Kryzys kary pozbawienia wolności (Warszawa: Wydawnictwo Wyższej Szkoły Menadżerskiej w Warszawie, 2011); Mariusz Sztaba, Anna Różyło (red.), Wychowanie w refleksji Karola Wojtyły - Jana Pawła II. Wybrane aspekty (Lub- 
Nie oznacza to jednak, że w pedagogice nie wykorzystuje się twierdzeń osób będących autorytetami religijnymi do uzasadniania opisów i diagnoz rzeczywistości społecznej czy kulturowej, a więc do uzasadniania tez empirycznych. Przykładowo, służą one definiowaniu takich zjawisk jak: kryzys kultury współczesnej, bezrobocie, sytuacja współczesnej rodziny ${ }^{42}$. Biorąc pod uwagę, że niekiedy ${ }^{43}$ prezentowane wypowiedzi dotyczą aspektów społecznych, kulturowych, politycznych, administracyjnych, medialnych czy psychicznych opisywanych zjawisk, otwartym pozostaje pytanie, na mocy jakiego rodzaju kompetencji twierdzenia formułowane przez autorytety religijne uznawane są w pedagogice za obowiązujące, zasadne. Czy uzasadnienie takie dotyczy statusu instytucjonalnego, jaki posiada określona osoba, czy jej wiedzy merytorycznej? Czy wypowiedziane tezy uznać należy za twierdzenia spełniające warunki naukowości ${ }^{44}$, czy raczej jako wypowiedzi indywidualnych osób, ewentualnie jako ewokację poglądów pewnej grupy osób lub stanowiska określonej instytucji? Pytania te wydają się o tyle ważne, że prócz bezpośredniego znaczenia (wartości) poznawczego wpisują się w kontekst dyskusji dotyczącej naukowego statusu pedagogiki. W jej zakresie natomiast chodzi o (nie takie rzadkie) roszczenie sobie prawa do kompetentnego wypowiadania się na tematy wchodzące w zakres wiedzy pedagogicznej przez naukowców różnych dziedzin, „ludzi kultury”, przedstawicieli religii czy wręcz ,zwykłych” ludzi ${ }^{45}$.

lin: Wydawnictwo KUL, 2015); Witold Starnawski, „Perspektywa religijna w doświadczeniu wychowania”, Paedagogia Christiana 1 (2013): 139-141; Krzysztof Gąsecki, „Aksjologiczny wymiar pracy ludzkiej - inspiracja myślą Jana Pawła II”, w: Pedagogika chrześcijańska. Tradycja - Współczesność - Nowe Wyzwania, red. Jarosław Michalski, Aldona Zakrzewska (Toruń: Wydawnictwo Adam Marszałek, 2010), 387-401.

42 Por. Magdalena Łuka, „Działania promujące osobę jako sposób rozwiązywania kwestii bezrobocia”, Roczniki Pedagogiczne 2 (2010): 117-120; Valéria Hrtánková, „Człowiek i rodzina chrześcijańska w XXI wieku - niebezpieczeństwa i wyzwania”, w: Człowiek u progu trzeciego tysiaclecia. Zagrożenia i wyzwania, t. 4, red. Mieczysław Plopa (Elbląg: Wydawnictwo Elbląskiej Uczelni Humanistyczno-Ekonomicznej, 2011), 292-293; Magdalena Parzyszek, „Dziecko w rodzinie współczesnej”, w: Dziecko w przestrzeni życia społecznego, red. Jadwiga Daszykowska, Andrzej Łuczyński (Stalowa Wola: Wydział Zamiejscowy Nauk o Społeczeństwie Katolickiego Uniwersytetu Lubelskiego Jana Pawła II w Stalowej Woli, 2013), 82.

${ }^{43}$ Nie polemizuję z zasadnością moralnych czy tym bardziej religijnych (teologicznych) ocen przedmiotowych zjawisk.

${ }^{44}$ Innym problemem jest trudność w określeniu takich warunków (kryteriów), będąca w znacznej mierze konsekwencją wieloznaczności terminu „,nauka”: por. Walczak, Racjonalność, 21-24.

45 Problem specyficzności wiedzy pedagogicznej poruszany jest np. przez Stefana Sar- 
Innym istotnym dla podjętych $\mathrm{w}$ niniejszym artykule analiz problemem pozostaje dyskusja dotycząca specyfiki poznania (języka) filozofii (jak sądzę także teologii). Nie wchodząc w szczegóły, zaznaczyć warto, że opis rzeczywistości z pozycji filozoficznej (i teologicznej) jest inny (wyrażony w odmiennym języku) niż opis rzeczywistości z pozycji nauk szczegółowych (humanistycznych czy przyrodniczych). Są to zdania możliwie ogólne, abstrakcyjne, z trudem operacjonalizowane, a być może także quasi-opisowe i/lub krypto-postulatywne ${ }^{46}$. Interpolacja twierdzeń filozoficzno-teologicznych autorytetów religijnych na teren nauk humanistycznych nie jest zatem oczywista. Wprowadza dyskusję dotyczącą możliwości ich operacjonalizacji i zakresu wykorzystania.

Odmienną sytuacją wydaje się ta, kiedy autorytety używane są w celu uzasadnienia ocen i norm. Wartościowanie traktowane jest jako szczególna sytuacja $\mathrm{w}$ nauce. Istnienie i uzasadnianie wartości stanowi przedmiot szerokich dyskusji. Wśród podstawowych typów uzasadnień wartości wymienia się te odwołujące się do określonego modelu kultury oraz religiii ${ }^{47}$. Wartości i normy formułowane przez autorytety kulturowe i religijne uznawane są za jedno ze źródeł norm i wartości, także w pedagogice.

Kończąc, pragnę zauważyć, że oprócz wspomnianych wyżej funkcji autorytety religijne $\mathrm{w}$ pedagogice (czy szerzej: w humanistyce) posiadać mogą funkcję ,przedteoretyczną”. Niezależnie od modelu naukowości, jaki przyjmujemy, wpływ autorytetów religijnych dotyczyć może osób samych naukowców. Chodzi o sytuacje, kiedy wypowiedzi (twierdzenia, opinie) autorytetów religijnych inspirują personalnie naukowców do podejmowania badań w określonym zakresie. Osobiste uznanie przez badacza autorytetu pewnych osób wpływać może na jego zainteresowania badawcze lecz także określać zespół założeń (w tym aksjologicznych) przyjmowanych w mo-

nowskiego, Andrzeja Bronka, zob. Stefan Sarnowski, „O krytyce rozumu pedagogicznego”, w: Krytyka rozumu pedagogicznego, red. Stefan Sarnowski (Bydgoszcz: Wyższa Szkoła Pedagogiczna w Bydgoszczy, 1993), 9-31; Bronk, „Czy pedagogika”, 47-76.

${ }^{46}$ O specyfice i trudnościach w operacjonalizacji kategorii filozoficznych na przykładzie kategorii „godności osoby”, zob.: Andrzej Bronk, „Pojęcie godności człowieka: uwagi metodologa", w: Antropologiczna pedagogika ogólna, red. Marian Nowak, Piotr Magier, Iwona Szewczak (Lublin: Wydawnictwo KUL, Wydawnictwo Gaudium, 2010), 65-69 oraz Monika Walczak, „Godność człowieka: kategoria opisowa, wartościująca, normatywna”, w: Antropologiczna pedagogika ogólna, red. Marian Nowak, Piotr Magier, Iwona Szewczak (Lublin: Wydawnictwo KUL, Wydawnictwo Gaudium, 2010), 76-80.

${ }^{47}$ Bronk, „Czy pedagogika”, 65-68. 
mencie podejmowania badań naukowych ${ }^{48}$. Nawet jeśli uznamy ograniczony zakres argumentatywnych funkcji autorytetów religijnych w pedagogice (humanistyce), odwołanie do wypowiedzi lub historii życia osób uznawanych za autorytety stanowić może istotny element „kontekstu odkrycia naukowego" (I. Lakatos) ${ }^{49}$, warunkując w ten sposób funkcjonowanie i rozwój nauki (pedagogiki).

\section{Religious Authorities in Pedagogy. Metatheoretical Remarks (Summary)}

The subject of the article is the functions, which in pedagogy are attributed to categories, statements and concepts of the people who are considered to be religious authorities. Many a time in this field of study, the used notions and thesis are formulated by people who are not scientists (e.g. by people who represent a particular religion or creed) in order to introduce justification or assessment of the particular postulates. The widespread use of the argument "from authority" raises questions about the need, legitimacy as well as the scope of this measure.

The article is metatopical and analytical in nature. It does not aim at constructing and calling for a model of the analysed relation. It is about formulating fundamental remarks describing theoretical functions, which are attributed to the statements of particular people who are considered to be religious authorities. Additionally, the notes formulated are apprising in nature, which emphasises the problem of the legitimacy of using arguments "from authority" in pedagogy.

Key words: pedagogy; authority; religious authorities; the autonomy of the study; epistemic authority; deontic authority; arguments "from authority"; demarcation; anti-demarcation.

\section{Autorytety religijne w pedagogice. Uwagi metateoretyczne (Streszczenie)}

Przedmiotem artykułu są funkcje przypisywane w pedagogice kategoriom, twierdzeniom i koncepcjom autorstwa osób uznawanych za autorytety religijne.

${ }^{48}$ Por. Gordon Marshall (red.), Stownik socjologii i nauk społecznych (Warszawa: Wydawnictwo Naukowe PWN, 2005), 416-417.

49 Por. Walczak, Racjonalność, 132. 
Niejednokrotnie w tej dyscyplinie wiedzy wykorzystywane są pojęcia i tezy formułowane przez osoby niebędące naukowcami (np. przez osoby reprezentujące określoną religię bądź wyznanie) w celu wprowadzenia, argumentowania lub oceny określonych postulatów. Powszechność użycia argumentu „z autorytetu” budzi pytania dotyczące potrzeby, zasadności oraz zakresu tego typu zabiegu.

Artykuł ma charakter metaprzedmiotowy oraz analityczny. Nie stawia sobie za cel skonstruowania i postulowania modelu analizowanej relacji. Chodzi o sformułowanie elementarnych uwag opisujących teoretyczne funkcje, jakie przypisuje się wypowiedziom określonych osób uznanych za autorytety religijne. Dodatkowo formułowane są uwagi o charakterze oceniającym, służące uwypukleniu problemu zasadności użycia argumentów „z autorytetu” w pedagogice.

Slowa kluczowe: pedagogika; autorytet; autorytety religijne; autonomia nauki; autorytet epistemiczny; autorytet deontyczny; argumenty „, autorytetu”; demarkacjonizm; antydemarkacjonizm.

\section{Bibliografia}

Bocheński, Józef Maria. „Autonomia uniwersytetu”. W: Józef Maria Bocheński. Sens życia i inne eseje, 60-71. Kraków: Wydawnictwo Philed, 1993.

Bocheński, Józef Maria. „O dialogu filozoficznym”. W: Józef Maria Bocheński. Sens życia i inne eseje, 125-135. Kraków: Wydawnictwo Philed, 1993.

Bocheński, Józef Maria. „Przeciw humanizmowi”. W: Józef Maria Bocheński. Sens życia i inne eseje, 23-39. Kraków: Wydawnictwo Philed, 1993.

Bocheński, Józef Maria. Sto zabobonów. Krótki filozoficzny stownik zabobonów. Kraków: Wydawnictwo Philed, 1994.

Bocheński, Józef Maria. Zarys historii filozofii. Kraków: Wydawnictwo Philed, 1993. Bronk, Andrzej. „Czy pedagogika jest nauką autonomiczną?”. W: W trosce o integralne wychowanie, red. Marian Nowak, Tomasz Ożóg, Alina Rynio, 47-76. Lublin: Wydawnictwo KUL, 2003.

Bronk, Andrzej. „Pojęcie godności człowieka: uwagi metodologa”. W: Antropologiczna pedagogika ogólna, red. Marian Nowak, Piotr Magier, Iwona Szewczak, 57-74. Lublin: Wydawnictwo KUL, Wydawnictwo Gaudium, 2010.

Bronk, Andrzej. Zrozumieć świat współczesny. Lublin: Towarzystwo Naukowe Katolickiego Uniwersytetu Lubelskiego, 1998.

Ceglarek, Roman, Mariusz Sztaba (red.). Być człowiekiem sumienia. Interdyscyplinarny namyst nad fenomenem sumienia. Częstochowa: Częstochowskie Wydawnictwo Archidiecezjalne Regina Poloniae, 2015. 
Chlewiński, Zdzisław, Stanisław Majdański. „Autorytet”. W: Encyklopedia Katolicka, T. I, red. Feliks Gryglewicz, Romuald Łukaszyk, Zygmunt Sułowski, 1161-1168. Lublin: Towarzystwo Naukowe Katolickiego Uniwersytetu Lubelskiego, 1985.

Drabik, Lidia i in. (oprac.). Słownik Języka Polskiego. Warszawa: Wydawnictwo Naukowe PWN, 2007.

Evans, Gillian Rosemary. Filozofia i teologia w Średniowieczu. Kraków: Wydawnictwo Znak, 1996.

Gąsecki, Krzysztof. „Aksjologiczny wymiar pracy ludzkiej - inspiracja myślą Jana Pawła II". W: Pedagogika chrześcijańska. Tradycja - Współczesność - Nowe Wyzwania, red. Jarosław Michalski, Aldona Zakrzewska, 387-401. Toruń: Wydawnictwo Adam Marszałek, 2010.

Horowski, Jarosław. „Wolność od autorytetu jako zabobon. Teleologia wychowania w zakresie autorytetu w świetle analiz Józefa Marii Bocheńskiego". Acta Universitatis Nicolai Copernici - Pedagogika XXV (2009): 29-46.

Hrtánková, Valéria. „Człowiek i rodzina chrześcijańska w XXI wieku - niebezpieczeństwa i wyzwania”. W: Człowiek u progu trzeciego tysiaclecia. Zagrożenia $i$ wyzwania, T. 4, red. Mieczysław Plopa, 291-296. Elbląg: Wydawnictwo Elbląskiej Uczelni Humanistyczno-Ekonomicznej, 2011.

Iwański, Zbigniew Stanisław. Kryzys kary pozbawienia wolności. Warszawa: Wydawnictwo Wyższej szkoły Menadżerskiej w Warszawie, 2011.

Jeziorański, Marek. Bł. Jana Pawła II koncepcja wychowania małżonków. Lublin: Wydawnictwo KUL, 2013.

Jusiak, Roman. „Refleksja o pedagogice i naukowych badaniach pedagogicznych”. W: Szkice z pedagogiki, opieki międzyludzkiej, pracy resocjalizacyjnej i pedagogii chrześcijańskiej, red. Roman Jusiak, Andrzej Łuczyński, Lidia Pietruszka, 13-40. Lublin: Wydawnictwo KUL, 2015.

Kamiński, Stanisław. Nauka i metoda. Pojęcie nauki i klasyfikacja nauk. Lublin: Towarzystwo Naukowe Katolickiego Uniwersytetu Lubelskiego, 1992.

Kostkiewicz, Janina. „Status i tożsamość pedagogiki katolickiej 20-lecia międzywojennego w Polsce". Paedagogia Christiana 1 (2013): 45-69.

Kunowski, Stefan. Podstawy współczesnej pedagogiki. Warszawa: Wydawnictwo Salezjańskie, 2001.

Łuka, Magdalena. „Działania promujące osobę jako sposób rozwiązywania kwestii bezrobocia". Roczniki Pedagogiczne 2 (2010): 117-120.

Magier, Piotr. „Aksjologiczno-normatywne i argumentatywne aspekty pedagogiki chrześcijańskiej”. W: Edukacyjny potencjał religii, red. Jerzy Bagrowicz, Jarosław Horowski, 163-183. Toruń: Wydawnictwo Naukowe Uniwersytetu Mikołaja Kopernika, 2012. 
Magier, Piotr. „Autorytet wychowawcy według koncepcji pedagogiki personalistycznej”. W: Personalizmus v procese humanizácje l'udskej spoločnost, red. Pavol Dancák, 277-291. Prešov: Prešovská Univerzita v Prešove, 2014.

Magier, Piotr. „Pedagogika ogólna w strukturze nauk pedagogicznych”. W: U podstaw tożsamości pedagogiki, red. Ryszard Skrzyniarz, Ewa Smołka, Stanisława Konefał, 31-49. Lublin: Wydawnictwo KUL, 2012.

Marshall, Gordon (red.). Stownik socjologii i nauk społecznych. Warszawa: Wydawnictwo Naukowe PWN, 2005.

Mezei, Balázs M. „Kryzys uniwersytetu”. Ethos 1-2 (2009): 29-51.

Nowak, Marian. „Edukacyjny potencjał pedagogiki religii - bogactwo doświadczenia ludzkiego do przekazania". W: Edukacyjny potencjat religii, red. Jerzy Bagrowicz, Jarosław Horowski, 53-78. Toruń: Wydawnictwo Naukowe Uniwersytetu Mikołaja Kopernika, 2012.

Nowak, Marian. „Tożsamość pedagogiki chrześcijańskiej”. Paedagogia Christiana 1 (2013): 25-44.

Nowak, Marian. Podstawypedagogiki otwartej. Lublin: Redakcja Wydawnictw KUL, 1999.

Parzyszek, Magdalena. „Dziecko w rodzinie współczesnej”. W: Dziecko w przestrzeni życia społecznego, red. Jadwiga Daszykowska, Andrzej Łuczyński, 81-94. Stalowa Wola: Wydział Zamiejscowy Nauk o Społeczeństwie Katolickiego Uniwersytetu Lubelskiego Jana Pawła II w Stalowej Woli, 2013.

Rynio, Alina. Integralne wychowanie w myśli Jana Pawła II. Lublin: Wydawnictwo KUL, 2004.

Sarnowski, Stefan. „O krytyce rozumu pedagogicznego”. W: Krytyka rozumu pedagogicznego, red. Stefan Sarnowski, 9-31. Bydgoszcz: Wyższa Szkoła Pedagogiczna w Bydgoszczy, 1993.

Starnawski, Witold. „Perspektywa religijna w doświadczeniu wychowania”. Paedagogia Christiana 1 (2013): 139-141.

Sztaba, Mariusz (oprac.). Benedykt XVI. „Aby na nowo odkryć radość w wierze...”. Antologia papieskich wypowiedzi na temat wiary, watpienia i ateizmu. Warszawa: Oficyna Wydawniczo-Poligraficzna ADAM, 2014.

Sztaba, Mariusz, Anna Różyło (red.). Wychowanie w refleksji Karola Wojtyły - Jana Pawta II. Wybrane aspekty. Lublin: Wydawnictwo KUL, 2015.

Śliwerski, Bogusław. http://sliwerski-pedagog.blogspot.com/2011/05/wkad-dzie-imysli-karola-wojtyy.html (21.08.2015).

Tatarkiewicz, Władysław. Historia filozofii. T. I. Filozofia starożytna i średniowieczna. Warszawa: Wydawnictwo Naukowe PWN, 1993.

Walczak, Monika. „Godność człowieka: kategoria opisowa, wartościująca, normatywna". W: Antropologiczna pedagogika ogólna, red. Marian Nowak, Piotr 
Magier, Iwona Szewczak, 75-85. Lublin: Wydawnictwo KUL, Wydawnictwo Gaudium, 2010.

Walczak, Monika. Racjonalność nauki. Problemy, koncepcje, argumenty. Lublin:

Towarzystwo Naukowe Katolickiego Uniwersytetu Lubelskiego, 2006.

Woroniecki, Jacek. „Program pedagogiki katolickiej”. W: Pedagogika katolicka.

Zagadnienia wybrane, red. Alina Rynio, 15-36. Stalowa Wola: Oficyna Wydawnicza Fundacji Uniwersyteckiej w Stalowej Woli, 1999. 
